\title{
Lessons in Love and Dancing (Hodina tance a lásky)
}

Author: Pavel Kohout

First Published: 1989

Translations: Danish (Dansetimen, 1989); Finnish (Saksalainen romanssi, 1989); German (Tanz- und Liebesstunde, 1991); Norwegian (Danse- og kjærlighetstimen, 1990); Swedish (En dans- och kärlekslektion, 1990); Japanese (Ai to shi no odori, 1993).

Film Adaptation: Hodina tance a lásky (Lessons in Love and Dancing), TV film, screenplay Jelena Mašínová, Pavel Kohout and Viktor Polesný; film director Viktor Polesný, premiered 2003.

About the Author: Pavel Kohout (1928) is a Czech novelist, playwright and poet. He was born in Prague. In the 1950s he worked as a journalist and dramaturg and in the 1960s he directed at Vinohrady Theatre in Prague. Though his early poetry praised socialism, he was expelled from the Communist Party in 1969 as a prominent representative of the Prague Spring. Oppressed during the so-called normalisation by the secret police and banned from public life, Kohout organised "house theatre" events in which performances of plays by banned authors were given in private flats. Kohout was a coauthor and one of the first signatories of Charter 77. In 1978, he started working at the Burgtheater in Vienna, while his Czech citizenship was revoked. From 1979, he lived in exile, mainly in Austria. After 1989, he divided his time between Vienna and Prague. He became famous as the author of more than forty plays, novels, and autobiographical writings.

Further Important Publications: $Z$ deníku kontrarevolucionáře (in German 1969, Czech original 1997, From the Diary of a Counterrevolutionary; autofiction); Amerika (with Ivan Klima, in German 1970, in Czech 1991, theatre adaptation of Franz Kafka's novel); Katyně (samizdat 1978, in German 1978; The Hangwoman; novel).

\section{Content and Interpretation}

The first nineteen chapters of the novel, which is subtitled "A German Romance”, describe June fifth through sixth, 1944, and the final chapter takes place on June fourth, 1966. It is set in Theresienstadt/Terezin in North Bohemia, originally a fortress from the 18th century, in which a Gestapo prison was established during the German occupation of Czech lands. Its fictional commander is Karl Kleinburger, who holds the rank of Obersturmbannführer in the Waffen-SS. When Kleinburger's daughter Kristina flees the ruins of the heavily bombarded Berlin to join her parents, she falls into the clutches of the young SS officer Wolfgang Weissmüller. Both of them have been indoctrinated with the Nazi worldview from an early age, and Kristina's blind faith in Nazi ideology is further

Ә Open Access. (c) 2021 Alfrun Kliems, published by De Gruyter. (c) BY-NC-ND This work is licensed under a Creative Commons Attribution-NonCommercial-NoDerivatives 4.0 License. https://doi.org/10.1515/9783110671056-059 
amplified by Wolfgang's fanaticism. Then, as a gift for Kristina's eighteenth birthday, Kleinburger arranges for his daughter to have dance lessons under a Hungarian Jewish prima ballerina, whom he fetches for this purpose from the Theresienstadt Ghetto, a staging area for deportation to the death camps. The dance instructor tells Kristina that she was previously scheduled to be sent to Auschwitz and now longs for her family. As a result, the naive Kristina arranges for her instructor to be deported, imagining that her family has now been happily reunited in their new homeland of "East Israel" (Kohout, 1994, p. 35). Weissmüller is sent to bring the dancer back to the ghetto. Instead, he rapes her on the way back and lets her drown in a moat.

The final chapter retrospectively recounts what happens next: After the war, the dancer's death is pinned on commander Kleinburger, who has been portrayed as a fundamentally punctilious bureaucrat, and Kleinburger receives the death sentence. His daughter survives, marries an American changing her name, and follows her new husband to the United States. After her husband's death, she remarries. Her new husband is a Jewish man named Isaac Feuerstein. Yet once again, the (retrospective) point of view remains in Theresienstadt, which is now a memorial to the former fortress-prison. While Kristina proves stubbornly defensive of her Nazi political views and unwilling to give them up, a postcard from Paraguay points to the survival of Weissmüller.

In the end, the multiple viewpoints of a third-person voice are disrupted by the first-person narrator who introduces himself as the author of the account. He contemplates his life, his own (Communist) blindness, and asks why "zealous patriots and believers transform into base executioners” (pp. 214-215). He concludes: "Couldn't any of us, in certain circumstances, become an executioner's assistant, and isn't it true that those who don't become one, owe more of that to their lucky star than to their strong character?” (p. 215). Viktor Polesný directed a 2003 film adaptation where the last chapter of the novel was not included.

\section{Main Topics and Problems}

Kohout's novel, framed as a romance, aims to contemplate the perversion of ideals, but goes beyond this to become a "banalisation of brutality" itself (Pynsent, 1990, p. 130). This is significantly compounded by the fact that the narrative exclusively adopts the perpetrators' perspectives while the victims remain mute or even invisible; at best. Culpability is bound up with cliché experiences of victimisation, as when Weissmüller's rape of the dancer is linked to his own childhood trauma of abuse by a man.

The subtitle "A German Romance" is manifested on two literal levels. First, it can be seen in the flirtation between Kristina and Wolfgang, which supplies the virtual prolepsis of the dutiful marriage between the Kommandant and his wife, a prolepsis later lost with the war. Second, it is a reference to the protagonist's romantically exalted devotion to Adolf Hilter and Nazism that she perceives as Messianic. It is about doomed idealism. 
This corresponds to a chiastic presentation of motifs: the recurring Biedermeierstyle of gender cravings, kitschy intimacy, idyllic descriptions of landscapes, and Kleinburger's eclectic autodidacticism, all juxtaposed against the overall horror of the Nazi regime. They both descend into stereotypes to the point of ridiculousness, as when Kristina describes the SS officer as a gold-headed "angel" and her second husband, the American Jew, as a black-eyed "Lucifer." Other German-Jewish love affairs are likewise trivialised, each romance embedded in ideologically coloured reasoning.

In Wolfgang Benz's view, this structural chiasmus divides the topos of Theresienstadt into the prison world, "ruled" by Kleinburger with "military correctness" and into the "corrupt and slovenly administered world" of the ghetto. Benz further writes that the spacial opposition reflects the faulty premise of a conflict between an idealistic Nazism with "integrity" with that of a Nazism of "excess" (Benz, 2015, p. 483). On one side lies Kleinburger, a "white raven" (Kohout, 1994, p. 28) and "decent Nazi" (p. 30); on the other side lies the "monster" Weissmüller, who is sadistic and clearly scarred by his childhood.

Other critics particularly stress a "cheap Freudianism" and a "feeble, often amoral, philosophising” (Pynsent, 1990, p. 133 and 135) and note that, on the level of craft, the "boundary between the narrator's and the characters' perspective repeatedly blurs" (Becher, 1990, p. 129). Finally, the stylistic failures included the pornographic voyeurism in his treatment of hypersexualised physicality, sociological templates including the choice of the half-denunciatory, half-exculpatory name "Kleinburger" (German for "petty-bourgeois") and the remarkably trivialising voice of the retrospective section.

\section{Cited Works}

Becher, P. (1990). „Der Keim einer starken Geschichte...“. Bohemia, 31(1), pp. 127-130. Benz, W. (ed.) (2015). Handbuch des Antisemitismus. Judenfeindschaft in Geschichte und Gegenwart, vol. 7. Berlin et al.: Walter de Gruyter. Kohout, P. (1994). Hodina tance a lásky. Praha: Český spisovatel. Pynsent, R. B. (1990). Kohout and the Banalisation of Brutality. Bohemia, 31(1), pp. 130-136.

\section{Further References}

Benz, W. (2013) Theresienstadt. Eine Geschichte von Täuschung und Vernichtung. München: C. H. Beck. Kosatík, P. (2001). Fenomén Kohout. Praha: Paseka. SchmidtHartmann, E. (1990). Pavel Kohout: Hodina tance a lásky. Proměny, 27(2), pp. 161-164. 